\begin{abstract}
Intra- and interannual variability of fecundity and egg size of lumpfish (Cyclopterus lumpus) were assessed for 2009 and for 2014-2019 and compared with fecundity estimates from 1967 and 1969. Downregulation of fecundity was apparent throughout ovary development, but the intensity was reduced close to spawning. The fecundity of fish spawning later in the year was higher than that of fish that spawned earlier. Carcass weight was a better predictor of fecundity than length. The model was improved through the addition of liver weight, but this led to an increase of $<1.0 \%$ in the explained variance in fecundity. Variation in fecundity between the periods studied (2009 and 2014-2019) was low; however, fecundity in these study periods was higher than in 1967 and lower than in 1969. Whether these differences were due to differences in methods could not be ruled out. Average egg diameter was positively correlated with fish size and decreased from the first to the second batch, and only limited variation between years was observed in this characteristic.
\end{abstract}

Manuscript submitted 24 October 2019. Manuscript accepted 10 August 2020. Fish. Bull. 118:250-267 (2020).

Online publication date: 27 August 2020. doi: 10.7755/FB.118.3.4

The views and opinions expressed or implied in this article are those of the author (or authors) and do not necessarily reflect the position of the National Marine Fisheries Service, NOAA.

\title{
Intra- and interannual variation in fecundity and egg size of lumpfish (Cyclopterus Iumpus) in Iceland
}

\author{
James Kennedy (contact author) ${ }^{1,2}$ \\ Halldór G. Ólafsson ${ }^{2}$ \\ Email address for contact author: james.kennedy@hafogvatn.is \\ ${ }^{1}$ Marine and Freshwater Research Institute \\ Fornubúđum 5 \\ 220 Hafnarfiörður, Iceland \\ 2 Biopol ehf. \\ Einbúastíg 2 \\ 545 Skagaströnd, Iceland
}

The number of eggs produced by an individual fish influences the reproductive potential of the population (Trippel, 1999); however, information on fecundity and the temporal and spatial variability in this trait is lacking for many fish species. Collection of information on fecundity is not routine for most fish stocks, and spawning stock biomass is generally used as a proxy for total egg production and reproductive potential, despite indications that total egg production and reproductive potential may not be proportional to spawning stock biomass (Marshall et al., 1998). Because fecundity is not routinely estimated, fecundity estimates from a single year, or a small number of years, may be used to estimate annual changes in total egg production (Gundersen et al., 2000; Blanchard et al., 2003; Mehault et al., 2010). This use of temporally limited fecundity data may be problematic because of potential variability in fecundity between years (Rideout and Morgan, 2007).

The lumpfish (Cyclopterus lumpus) (Fig. 1) is a semi-pelagic species that inhabits temperate and Arctic regions of the North Atlantic Ocean. In the eastern Atlantic Ocean, it ranges from $80^{\circ} \mathrm{N}$, around Svalbard, Norway
(Eriksen et al., 2014), to $50^{\circ} \mathrm{N}$ in the English Channel (Ellis, 2015). In the western Atlantic Ocean, this species ranges from $56^{\circ} \mathrm{N}$ on the western coast of Greenland to around Newfoundland, Canada, and as far south as New England at about $42^{\circ} \mathrm{N}$ (Gregory and Daborn, 1982; Rackovan and Howell, 2017). Outside of the spawning period, juveniles and adults are distributed over open water, generally in the upper $50 \mathrm{~m}$ of the water column (Holst, 1993; Rosen and Holst, 2013) with adults migrating to coastal areas to spawn as the spawning period approaches.

Male lumpfish migrate to the coast before females, presumably to seek out and establish territory and spawning sites in preparation for the arrival of females. In Iceland, males arrive in January-February, and most females appear in March. Lumpfish spawn around Iceland from January through August; however, an individual fish will spawn only 2 batches of eggs with approximately 10-14 d between spawning events (Fulton, 1907; BoltonWarberg ${ }^{1}$; Kennedy, 2018). Although

\footnotetext{
${ }^{1}$ Bolton-Warberg, M. 2018. Personal commun. Ryan Inst., Natl. Univ. Ireland, University Rd., Galway H91 TK33, Ireland.
} 


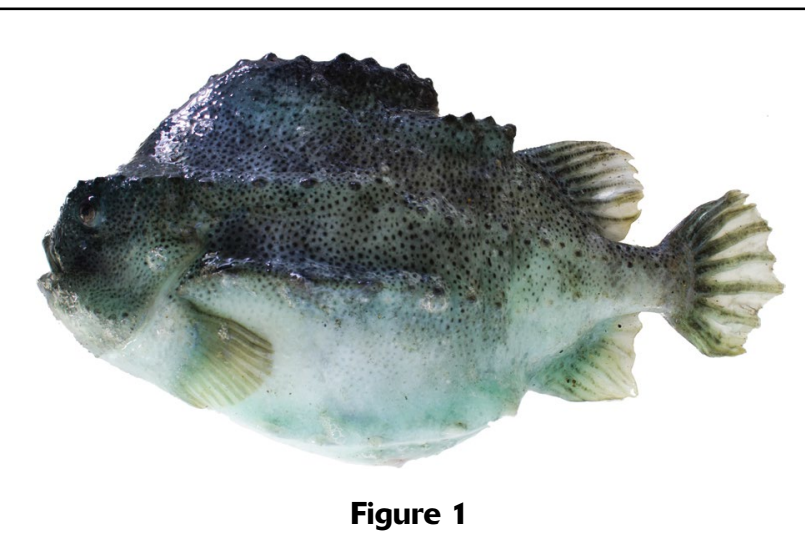

Photograph of a female lumpfish (Cyclopterus lumpus) collected at Skagaströnd, Iceland, in 2014 from the landings of the female lumpfish fishery that operates in Húnaflói Bay.

females approach the coast of Iceland in spring, they remain in deeper water $(\sim 50-300 \mathrm{~m})$ until they are very close to spawning (Kennedy and Jónsson, 2017). Lumpfish spawn as deep as $\sim 40 \mathrm{~m}$ to as shallow as a few meters below the low tide mark (Fulton, 1907; Todd et al., 2018). When ready to spawn, a female seeks out a male and lays her eggs in its nesting site. A male will then care for and defend the eggs until they hatch (Fulton, 1907). It is during this time, when they are in coastal areas, that females are targeted by a commercial fishery for their roe.

The precise timing of when ovary development begins in lumpfish is not known. However, vitellogenesis in preparation for spawning the following year is already underway in July (Kennedy, 2018). Therefore, ovary development takes at least 8 months to complete. During early vitellogenesis, there is a single mode of oocytes within the ovary. When the oocyte diameter of the leading cohort (LC) reaches approximately $2.0 \mathrm{~mm}$, a hiatus forms in the oocyte distribution creating 2 groups of oocytes. One group consists of small oocytes (diameters $<1800 \mu \mathrm{m}$ ) that are not spawned and presumably become atretic and are reabsorbed; this group is referred to as the non-spawning group (Kennedy, 2018). The other group comprises large oocytes (diameters $>1800 \mu \mathrm{m}$ ) and is considered the spawning group because its oocytes will be spawned during the current spawning season. A second hiatus forms within the spawning group, creating 2 batches of oocytes that are spawned separately. Because no oocytes are recruited into the vitellogenic pool after spawning has begun, the lumpfish is considered a determinate spawner (i.e., the maximum potential fecundity is set before spawning has begun). Therefore, it is possible to determine potential fecundity of lumpfish by estimating the number of oocytes within the spawning group. However, this maximum potential fecundity may not represent realized fecundity (the actual number of eggs spawned) because fecundity may be reduced as a result of downregulation, the process whereby the number of developing oocytes is reduced as ovary development progresses.
The aim of this study was to assess the potential fecundity of lumpfish in Iceland and how it varies with ovary development, within the spawning season and between years. The fecundity estimates from this study were compared with historical estimates made in 1967 and 1969. Because lumpfish spawn only 2 batches of oocytes and the batches are easily distinguished and do not hydrate their eggs, we took the opportunity to assess variation in egg size between individuals, batches, and years.

\section{Materials and methods}

\section{Collection of samples}

Lumpfish were sampled during scientific surveys and from landings of the commercial fishery for female lumpfish during 2009 and 2013-2019 (Table 1, Fig. 2). The Icelandic groundfish surveys took place annually during autumn (September-October) and spring (February-March). The samples collected from the commercial fishery were landed in 3 harbors: Skagaströnd, Stykkishólmur, and Pórshöfn. The fish landed at these harbors are caught in Húnaflói Bay, in Breiðafjörður, and on the northern coast of Langanes, respectively (Fig. 2). Fish landed in Skagaströnd accounted for $96 \%$ of the fish sampled from the commercial fishery. Lumpfish are known to move between these areas during the spawning season; therefore, taking fish from different areas likely did not affect results of this study (Kennedy et al., 2015).

During surveys, ovaries were sampled from fish within $1 \mathrm{~h}$ of capture. Fish collected from the fishery were covered in crushed ice upon landing, and ovaries were sampled within $24 \mathrm{~h}$. For each fish, total length (to the nearest centimeter) and total body, carcass, liver, and gonad mass (with a precision of $2 \mathrm{~g}$ ) were measured. For fish caught in the fishery, mass of the stomach contents and mass of the stomach and intestines were measured. A macroscopically assessed ovary developmental stage (Kennedy, 2018) (Table 2) and a spawning year, the calendar year in which it was next expected to spawn, was assigned to each fish.

\section{Ovary sampling}

All tissue and oocyte samples were placed in 45-mL tubes containing $10 \%$ buffered formalin, but the sampling varied depending on the developmental stage assigned because of differences in the organization of the ovary. Ovaries at the developing stage are homogeneous, and ovaries at the stage called spawning 1 are not. At the developmental stage spawning 1 , ovulation of the first batch of eggs has occurred; therefore, both developing oocytes and ripe eggs are present within the ovary (Kennedy, 2018). The developing oocytes are located in the dorsal area of the ovary, while the eggs are located in the ventral area. For fish classified as in the developing stage, 4-6 g of ovarian tissue was taken from the caudad area of the ovary. For fish at the stage spawning 1 , 


\section{Table 1}

Summary of information for female lumpfish (Cylopterus lumpus) collected around Iceland from groundfish surveys conducted in spring (February-March) and autumn (September-October) and from landings of the commercial fishery in 2009 and 2013-2019 and for lumpfish examined during previous studies in 1967 and 1969 (Schopka, 1970; Myrseth, 1971). Information includes year, source of fish sampled or of data, start and end dates of sampling, mean size and size range of fish sampled in total length (TL), number of lumpfish sampled ( $n$ ), and the number of lumpfish with ovaries assigned to each stage of oocyte size frequency distribution (OSFD). The sum of the number of lumpfish with ovaries at each OSFD stage is not always equal to the total number of sampled fish because some fish had ovaries for which the OSFD stage was ambiguous and, therefore, were excluded from all analyses. No lumpfish had ovaries at OSFD stage 1.

\begin{tabular}{|c|c|c|c|c|c|c|c|c|c|c|c|}
\hline \multirow[b]{2}{*}{ Year } & \multirow{2}{*}{$\begin{array}{c}\text { Sample or } \\
\text { data source }\end{array}$} & \multirow{2}{*}{$\begin{array}{l}\text { Start } \\
\text { date }\end{array}$} & \multirow{2}{*}{$\begin{array}{l}\text { End } \\
\text { date }\end{array}$} & \multirow{2}{*}{$\begin{array}{l}\text { Mean size } \\
(\mathrm{cm} \text { TL })\end{array}$} & \multirow{2}{*}{$\begin{array}{l}\text { Size range } \\
(\mathrm{cm} \mathrm{TL})\end{array}$} & \multirow[b]{2}{*}{$n$} & \multicolumn{5}{|c|}{ OSFD stage } \\
\hline & & & & & & & 2 & 3 & 4 & 5 & 6 \\
\hline 1967 & Schopka & 7 April & 28 April & 42 & $37-51$ & 48 & & 48 & & & \\
\hline 1969 & Myrseth & 1 May & 1 May & 42 & $35-48$ & 50 & & 50 & & & \\
\hline 2013 & Autumn & 2 Oct. & 9 Oct. & 39 & $32-45$ & 16 & 12 & & & & \\
\hline 2014 & Autumn & 5 Oct. & 18 Oct. & 39 & $32-47$ & 30 & 29 & & & & \\
\hline 2015 & Autumn & 09 Oct. & 1 Nov. & 39 & $31-51$ & 54 & 50 & & & & \\
\hline 2014 & Spring & 1 Mar. & 16 Mar. & 40 & $34-49$ & 50 & 29 & 19 & & & \\
\hline 2015 & Spring & 4 Mar. & 15 Mar. & 40 & $34-48$ & 65 & 37 & 28 & & & \\
\hline 2016 & Spring & 26 Feb. & 18 Mar. & 40 & $34-49$ & 92 & 63 & 29 & & & \\
\hline 2017 & Spring & 27 Feb. & 13 Mar & 41 & $34-53$ & 198 & 99 & 94 & & 3 & \\
\hline 2018 & Spring & 10 Mar. & $21 \mathrm{Mar}$ & 40 & $33-47$ & 84 & 44 & 38 & & 2 & \\
\hline 2009 & Fishery & 5 May & 3 June & 38 & $31-48$ & 172 & & 172 & & & \\
\hline 2014 & Fishery & 10 April & 3 July & 40 & $30-47$ & 71 & 3 & 32 & 20 & 8 & 7 \\
\hline 2015 & Fishery & 24 Mar. & 22 May & 41 & $34-48$ & 120 & 5 & 77 & 26 & 5 & 7 \\
\hline 2016 & Fishery & 21 Mar. & 30 May & 40 & $34-48$ & 221 & 8 & 118 & 70 & 9 & 14 \\
\hline 2017 & Fishery & 31 Mar. & 7 June & 41 & $34-50$ & 200 & 1 & 76 & 88 & 15 & 17 \\
\hline 2018 & Fishery & 3 April & 16 May & 39 & $35-46$ & 159 & & 93 & 47 & 13 & 6 \\
\hline 2019 & Fishery & 4 April & 21 May & 41 & $35-51$ & 242 & & 154 & 60 & 11 & 12 \\
\hline
\end{tabular}

a sample of ovarian tissue containing developing oocytes and a sample of eggs were taken and stored in separate tubes. A sample of eggs and a section of ovarian tissue were taken from fish at developmental stage spawning 2 and were stored in the same tube. At the stage spawning 2, the second batch of eggs has been ovulated, and the ovary is again homogenous.

For fish sampled in 2009, fecundity was estimated by using the gravimetric method, and ovaries were not preserved in formalin. A single sample of $\sim 5 \mathrm{~g}$ was weighed with a precision of $0.0001 \mathrm{~g}$, and the number of oocytes within the sample was counted. These measurements were used to calculate the oocyte density, which was then used with the fresh ovary weight to calculate fecundity.

\section{Calibration of an auto-diametric method}

For fish sampled in 2013-2019, fecundity was estimated by using a combination of gravimetric and auto-diametric methods (Thorsen and Kjesbu, 2001). Calibration between the gravimetric and auto-diametric methods was done with samples collected during the autumn groundfish survey conducted in 2014 (number of fish sampled $[n]=30$ ) and the spring survey conducted in $2015(n=65)$, along with samples collected from the fishery in $2015(n=61)$.
Because of the timing of sampling, few fish had oocytes with diameters of $0.8-1.2 \mathrm{~mm}$; therefore, fish from the autumn groundfish survey conducted in 2015 with a gonadosomatic index $>5(n=12)$ were also included in the calibration.

The samples analyzed gravimetrically were collected in pre-weighed tubes, and as a result, the initial weight of the ovarian tissue was known. The ovarian tissue was blot-dried and weighed, and the decrease in weight due to preservation was calculated. Three subsamples were then taken and weighed, either at a precision of $0.0001 \mathrm{~g}$ for the samples taken from the autumn survey or to the nearest $0.001 \mathrm{~g}$ for samples taken from the spring survey and the fishery. The oocytes in each subsample were separated from the connective tissue by using fine paintbrushes and were photographed under a dissecting microscope; a magnification of $12.5 \times$ was used for the autumn survey samples, and a $7 \times$ magnification was used for samples from the spring survey and fishery. The images were then analyzed with ImageJ software (vers. 1.49b; Rasband, 2014) and the ObjectJ plug-in (vers. 1.03s, University of Amsterdam, available from website), which were used to measure the diameter of all oocytes present in each image. Light level was standardized by using distilled water and a gray level set at $207( \pm 2)$. Ovaries were 


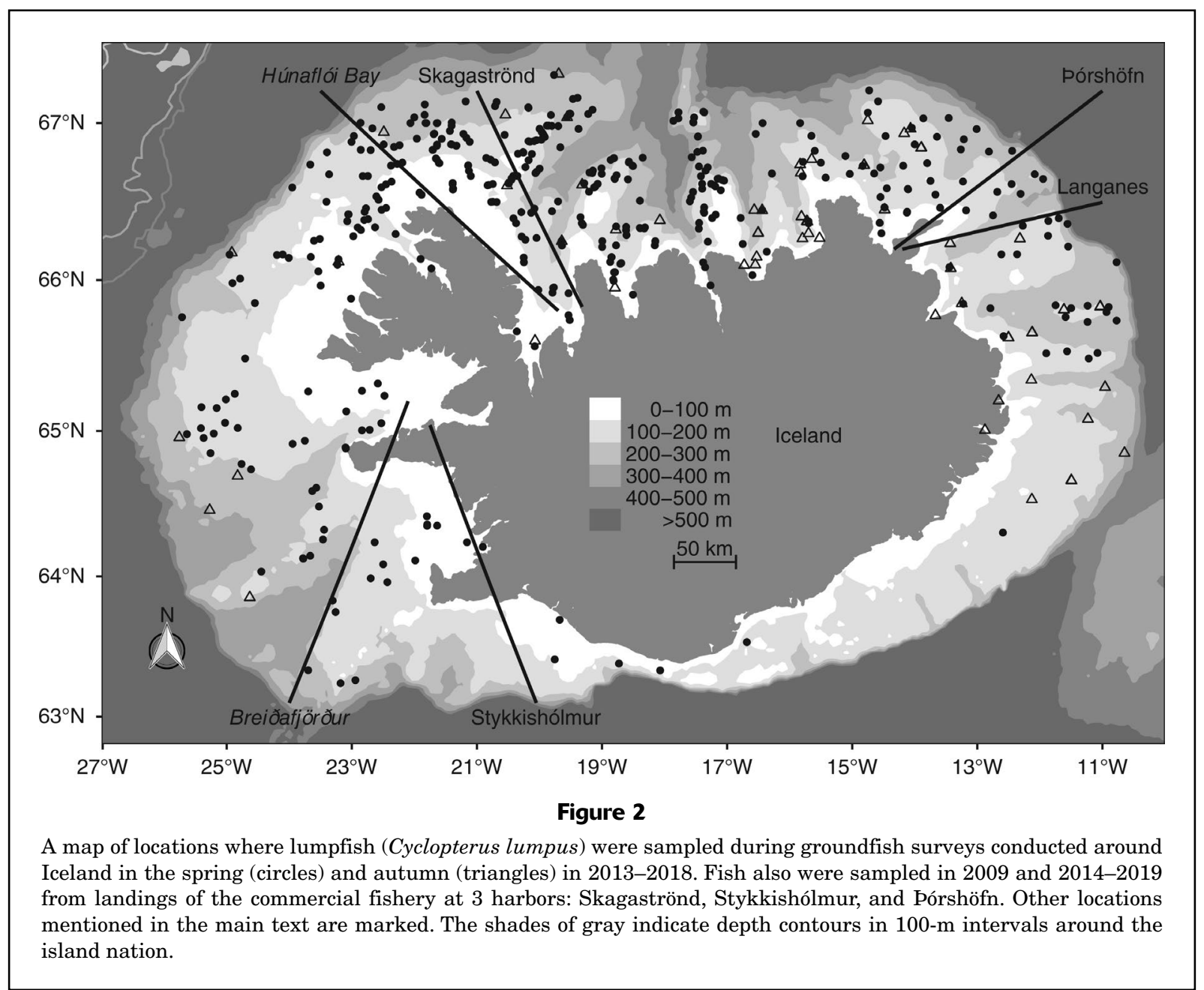

assigned a stage of oocyte size frequency distribution (OSFD) (Kennedy, 2018) (Table 2). An OSFD stage could not be assigned to a small number of ovaries because the OSFD was ambiguous; these fish were excluded from all analyses. By using the data from the image analysis, several characteristics were calculated for each subsample and ovary, including average oocyte diameter, LC oocyte diameter, and oocyte density.

Average oocyte diameter For ovaries assigned to OSFD stage 2 , the average diameter was calculated from all oocytes $\geq 400 \mu \mathrm{m}$. For ovaries assigned to OSFD stages 3,4 , and 5 , average diameter was calculated for all the oocytes in the spawning group. Average oocyte diameter was not calculated for oocytes at OSFD stage 6. No lumpfish had ovaries at OSFD stage 1.

Leading cohort oocyte diameter For ovaries assigned to OSFD stage 2, the LC oocyte diameter was calculated from the largest $10 \%$ of oocytes $\geq 400 \mu \mathrm{m}$. For ovaries assigned to OSFD stages 3 and 5, LC oocyte diameter was calculated from the largest 10\% of oocytes in the spawning group. Leading cohort oocyte diameter was used as an indicator of the progression of ovary development (Kjesbu, 1994). Leading cohort oocyte diameter was not calculated for ovaries at OSFD stages 4 or 6 .

Oocyte density of subsamples For ovaries assigned to OSFD stage 2, the oocyte density of the subsamples was from the number of oocytes $\geq 400 \mu \mathrm{m}$ in the subsample divided by the weight of the subsample. For ovaries assigned to OSFD stages 3,4 , and 5 , the oocyte density of the subsamples was calculated from the number of oocytes in the spawning group divided by the weight of the subsample. Oocyte density of each ovary was estimated by taking the average oocyte density of the 3 subsamples. Oocyte density of the developing oocytes of ovaries at OSFD stage 4 (in which the ovary contains developing oocytes and ripe eggs) was estimated to investigate whether the number of batches present within the spawning group affected the relationship between oocyte diameter and oocyte density. Oocyte density was not calculated for ovaries at OSFD stage 6 .

Some ovaries from the autumn survey contained a small number of residual eggs that were not spawned; these samples were excluded from the calibration between 


\section{Table 2}

Descriptions of the macroscopically determined stages of ovary development, or maturity, and the stages of oocyte size frequency distribution (OSFD) used to assess lumpfish (Cyclopterus lumpus) collected around Iceland from groundfish surveys and from landings of the commercial lumpfish fishery during 2009 and 2013-2019. This table essentially is reproduced from Kennedy (2018).

\begin{tabular}{ll}
$\begin{array}{l}\text { Macroscopic } \\
\text { stage }\end{array}$ & \multicolumn{1}{c}{ Description } \\
\hline Immature & $\begin{array}{l}\text { Ovary is small, and no developing oocytes are } \\
\text { visible. }\end{array}$ \\
Developing & $\begin{array}{l}\text { Ovary has increased in size and is easy to distin- } \\
\text { guish in the body cavity. Oocytes within the ovary } \\
\text { are clearly visible. Ovary can be orange, purple, or } \\
\text { green. A small amount of fluid may be close to the } \\
\text { oviduct on the ventral area of the ovary; this fluid } \\
\text { should not be confused with the large amount of } \\
\text { viscous ovarian fluid and eggs seen in the spawn- } \\
\text { ing stage. }\end{array}$
\end{tabular}

Spawning 1 Separation in the ovary is clear. There are developing oocytes in the dorsal area of the ovary and ripe eggs in the ventral area of the ovary. The developing oocytes are connected to ovarian tissue. The eggs look "wet," are not connected to the ovarian tissue, flow freely within the ovary, and are bathed within a viscous ovarian fluid.

Partially Ovary is similar in appearance to, and difficult to spent discern from, an ovary in the developing stage.

Spawning 2 Ovary is flaccid and contains mostly ripe eggs, which flow freely within the ovary. The eggs are not connected to ovarian tissue and are bathed within a viscous ovarian fluid. The dorsal area of the ovary wall has a "banded" appearance.

Spent
Ovary is flaccid, and a small number of residual eggs may be visible.

\section{OSFD}

stage

Description

1 Ovary contains only previtellogenic oocytes.

$2 \quad$ The oocyte size frequency distribution indicates a single group of oocytes within the ovary with diameters of almost all oocytes $<1800 \mu \mathrm{m}$. Distribution is unimodal and, as ovary development progresses, becomes negatively skewed.

A hiatus has formed in distribution at diameters around 1400-1600 $\mu \mathrm{m}$, separating oocytes into 2 distinct groups. The group of large oocytes (with diameters typically $>1800 \mu \mathrm{m}$ ) has a bimodal distribution, and the distribution of the group with small oocytes $(\leq 1800 \mu \mathrm{m})$ is variable. In a small number of cases, the small oocytes may not be present.

Ovary contains developing oocytes and ripe eggs. The eggs are larger than the developing oocytes. Both the eggs and developing oocytes have a unimodal size distribution. There may also be a group of small oocytes (diameters $<1800 \mu \mathrm{m}$ ) with a variable size frequency distribution.

There may be 1 or 2 groups of oocytes present within the ovary. A group of large oocytes (with diameters typically $>1800 \mu \mathrm{m}$ ) has a unimodal distribution, and the size frequency distribution of the group with small oocytes $(\leq 1800 \mu \mathrm{m})$ is variable. In a small number of cases, the small oocytes may not be present.

6

Ovary contains a single group of ripe eggs that have a unimodal distribution. There may also be a group of small oocytes (diameters $<1800 \mu \mathrm{m}$ ), with a variable size frequency distribution.

7
Ovary may contain a small number of residual eggs or oocytes with a size distribution similar to that of oocytes at stage 2,3 , or 6 . gravimetric and average oocyte diameter, as well as from all fecundity analyses, because of concerns about nonhomogeneity of the ovary.

Measurements of oocyte size and oocyte density were $\log _{10}$-transformed, and general linear models were fitted by using $\mathrm{R}$ (vers. 3.6.1; R Core Team, 2019). These models were used to estimate oocyte density from measurements of oocyte size.

\section{Estimation of fecundity with the auto-diametric method}

Fecundity was estimated by using the auto-diametric method for fish with ovaries at OSFD stages 2, 3, and 5 . For each fish, a small piece of preserved ovary was blotted to remove excess formalin; then the oocytes were separated and photographed. Images were analyzed and average oocyte diameter was calculated in a manner similar 
to that described previously. For each fish, a minimum of 150 oocytes $\geq 400 \mu \mathrm{m}$ were measured. Oocyte density was estimated from average oocyte diameter by using the relationships described previously (see the "Results" section). Fecundity could then be estimated by multiplying oocyte density by weight of preserved ovary (see the "Results" section). Fecundity was estimated only for fish with an average oocyte diameter $>550 \mu \mathrm{m}$, the minimum average oocyte size used in the oocyte diameter-oocyte density calibration. Leading cohort oocyte diameter was calculated for each fish in a similar manner to that previously mentioned.

Because oocytes were not measured for samples collected in 2009, the LC oocyte diameter for these samples was calculated on the basis of a linear relationship between $\log _{10}$-transformed oocyte density (calculated as fecundity divided by ovary weight) and $\log _{10}$-transformed LC oocyte diameter. From this relationship, LC oocyte density was calculated with this equation:

$$
\begin{aligned}
\log _{10}(\text { LC oocyte diameter })= & 3.94+\log _{10}(\text { oocyte } \\
& \text { density }) \times-0.27 .
\end{aligned}
$$

Eighty eggs were measured from ovaries at the developmental stages spawning 1 or spawning 2. Preservation in formalin does not affect diameter of oocytes because lumpfish lay demersal eggs that are not hydrated (senior author, unpubl. data).

\section{Effects of preservation}

Because the auto-diametric method was calibrated by using ovaries preserved in $10 \%$ formalin, the effect of preservation on fresh ovary weight was examined by using the same ovaries used in the auto-diametric calibration. On the basis of these results, preserved ovary weight was estimated by using a combination of average oocyte diameter and fresh ovary weight (see the "Results" section).

\section{Historical estimates}

Data on fecundity for 1967 and 1969 were extracted by using digitized images of plots of fecundity versus length from Schopka (1970) and Myrseth (1971). A sampling date was assigned to the data from each study. Schopka (1970) sampled fish during 7-28 April 1967; because it was not possible to assess a specific sampling date to each fish, they were all assigned a day midway through the sampling period: 16 April. Myrseth (1971) collected samples on 1 May 1969.

\section{Statistical analysis}

General linear models were fitted to the data, and the best models were chosen on the basis of the coefficient of determination $\left(r^{2}\right)$ and the Akaike information criterion (AIC). Variables included in the models were length, carcass weight, liver weight, date of capture (expressed as day of year), and spawning year. Carcass weight was included in the models, as opposed to whole body weight, because part of whole body weight was composed of ovary weight, which was used to estimate fecundity. In addition, large amounts of water and food (up to $800 \mathrm{~g}$ or $23 \%$ of total body mass) were present in many stomachs from the fish caught during the spring and autumn surveys but not in those from fish sampled from the commercial fishery. Date of capture was converted to a numerical number (1-365), with 1 September rather than 1 January as day 1 because fish in the same ovary development cycle were captured before and after 1 January.

Expected fecundity before spawning of the first batch was calculated for fish with ovaries at OSFD stage 5 by using the general linear model of fecundity=length+date of capture, fitted to data from fish with ovaries at OSFD stage 3 . The date of capture of the fish with ovaries at OSFD stage 5 was set as $14 \mathrm{~d}$ prior to their date of capture on the basis of the assumption of $14 \mathrm{~d}$ between the spawning of the first and second batches of eggs (Fulton, 1907). The result of actual fecundity divided by expected fecundity for fish with ovaries at OSFD stage 5 gives an indication of the proportion of eggs spawned in the first batch of eggs (e.g., a value of 0.50 would indicate that approximately half of the eggs were spawned in the first batch and the remaining half would have been spawned in the second batch). The resultant values of proportion of eggs spawned were tested, with a 1-sample Student's $t$-test, to determine whether the mean proportion of eggs spawned for all ovaries assigned to OSFD stage 5 was significantly different from 0.50. Carcass weight was not used to predict fecundity for fish with ovaries assigned to OSFD stage 5 because carcass weight at length was lower for fish at this stage than for fish with ovaries at OSFD stage 3 , indicating carcass weight decreased during the time between these stages. Length was not expected to change between stages.

\section{Ovaries containing eggs}

Because of the heterogeneous nature of the ovary, fecundity could not be estimated for ovaries that contained ripe eggs (i.e., ovaries at stages spawning 1 and spawning 2). Average diameter of the developing oocytes and eggs was measured in a manner similar to that described previously. The effect of carcass weight and batch number was investigated by using general linear models, with oocyte diameter and carcass weight $\log _{10}$ transformed. Possible effects of spawning year were investigated by using a Tukey's honestly significant different (HSD) test.

\section{Results}

\section{Calibration of the auto-diametric method}

For ovaries at OSFD stage 2 (on the basis of $\log _{10^{-}}$ transformed data), there was a significant negative linear correlation between average oocyte diameter and oocyte density (linear regression: $n=88, r^{2}=0.99, P<0.001$ ) (Fig. 3). 


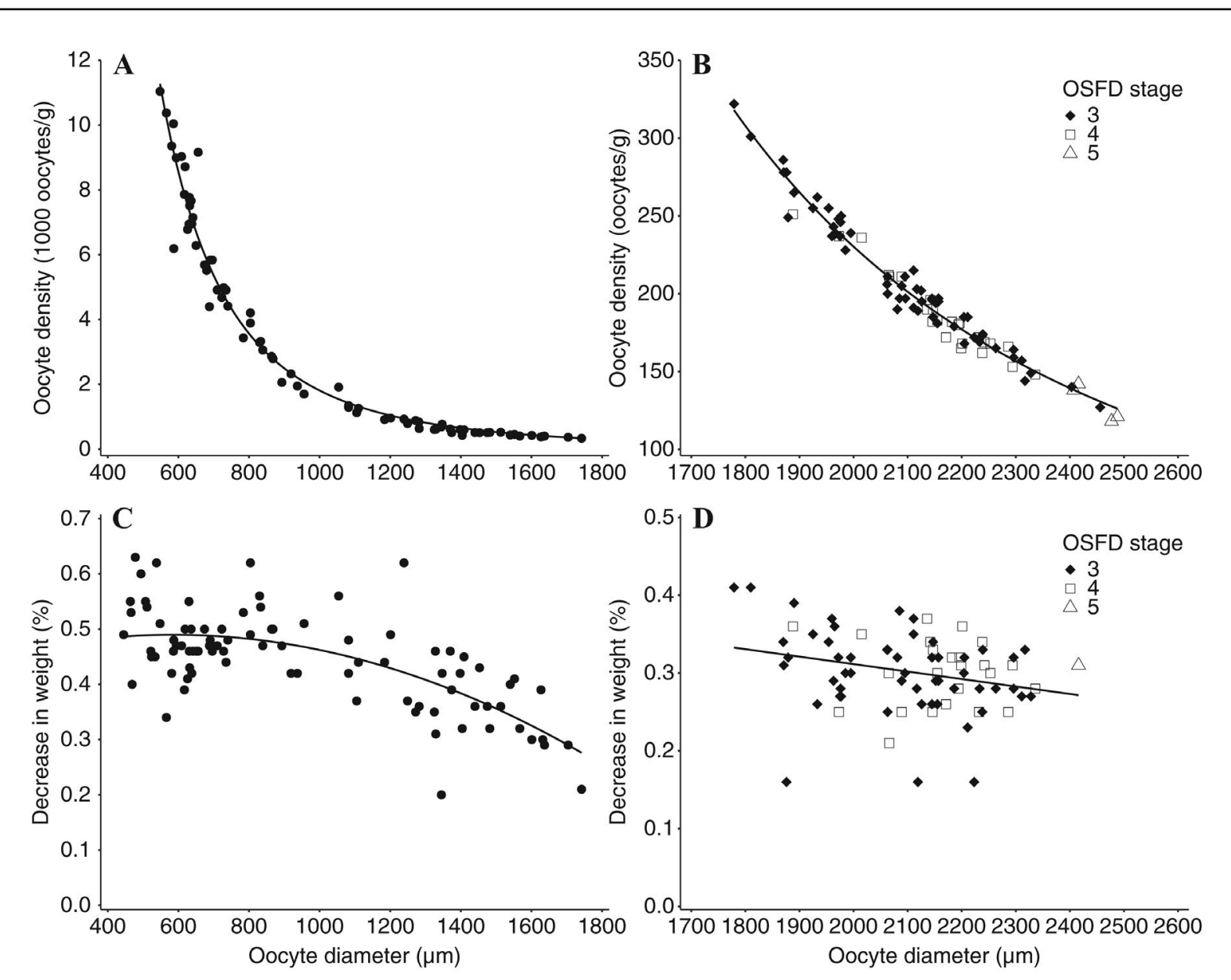

Figure 3

Relationships between oocyte diameter and oocyte density of lumpfish (Cyclopterus lumpus) with ovaries at oocyte size frequency distribution (OSFD) (A) stage 2 and (B) stages 3 (diamonds), 4 (squares), and 5 (triangles) and relationships between oocyte diameter and the decrease in weight of ovaries due to preservation in $10 \%$ formalin for lumpfish with ovaries at $(\mathbf{C})$ stage 2 and (D) stages 3, 4, and 5. Lines indicate the power regression in panels A and $\mathrm{B}$, polynomial regression in panel $\mathrm{C}$, and linear regression in panel $\mathrm{D}$. Ovaries classified as at OSFD stage 2 contain a single group of oocytes between 400 and $1800 \mu \mathrm{m}$ with a unimodal size frequency distribution. In ovaries classified as at OSFD stage 3, a break in size frequency distribution separates oocytes into a group of large oocytes (diameters $>1800 \mu \mathrm{m}$ ) that have a bimodal distribution and a group of small oocytes (diameters $\leq 1800 \mu \mathrm{m}$ ) that have a variable distribution; the oocyte diameter and oocyte density refer to the group of large oocytes. At OSFD stage 4, ripe eggs and developing oocytes have a unimodal distribution; the oocyte diameter and oocyte density refer to the developing oocytes. At OSFD stage 5, a group of large oocytes has a unimodal distribution and, if present, a group of small oocytes has a variable distribution. Lumpfish were sampled around Iceland in 2009 and 2013-2019 during groundfish surveys and from commercial fishery landings.

By using these data and the following equation, oocyte density was estimated for ovaries at this stage:

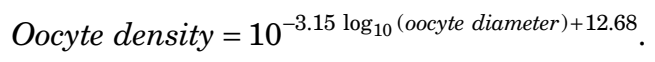

There was no significant difference in the relationship between average oocyte diameter and oocyte density for fish with 2 batches of oocytes in the spawning group (ovaries assigned to OSFD stage 3) and fish with 1 batch of oocytes in the spawning group (ovaries assigned to OSFD stage 4 or 5) (general linear model: $P>0.05$ ); therefore, the data from these 3 stages were combined. The $\log _{10^{-}}$ transformed data indicate that there was a significant negative linear correlation between average oocyte diameter and oocyte density (linear regression: $n=85, r^{2}=0.97$, $P<0.001$ ) (Fig. 3). By using these data and the following equation, oocyte density was estimated for ovaries at the OSFD stages $3-5$ :

$$
\text { Oocyte density }=10^{\left.-2.79 \log _{10} \text { (oocyte diameter }\right)+11.57} .
$$




\section{Effects of preservation}

The decrease in weight of ovarian tissue after fixation in formalin for ovaries in OSFD stage 2 was correlated with average oocyte diameter, and on the basis of AIC values, a second order polynomial regression gave the best fit to the data (polynomial regression: $n=86, r^{2}=0.46$ ) (Fig. 3 ). The weight of ovaries, adjusted for the effect of preservation, was calculated by using this equation:

$$
\begin{aligned}
\text { Preserved weight }= & \text { fresh weight }\left(1-\left[\left(1.87 \times 10^{-4}\right.\right.\right. \\
& \text { oocyte diameter })+\left(-1.6 \times 10^{-7}\right. \\
& \text { oocyte diameter } \left.\left.\left.{ }^{2}\right)+0.44\right]\right)
\end{aligned}
$$

The decrease in weight of ovarian tissue after fixation in formalin for ovaries in OSFD stages 3 and 5 was negatively and linearly correlated with average oocyte diameter (linear regression: $n=78, r^{2}=0.06$ ) (Fig. 3). The weight of ovaries, adjusted for the effect of preservation, was calculated by using this equation:

$$
\begin{aligned}
\text { Preserved weight }= & \text { fresh weight } \times\left(1-\left[-9.6 \times 10^{-5}\right.\right. \\
& \text { oocyte diameter }+0.5]) .
\end{aligned}
$$

\section{Fecundity and ovary development}

It is common to $\log _{10}$ transform fecundity and body size data for fish in order to satisfy the assumptions of linear regression. However, general linear models of untransformed data gave a better fit than $\log _{10}$-transformed data, with coefficients of multiple determination $\left(R^{2}\right)$ of 0.42 and 0.38 for the general linear model of fecundity and carcass weight with untransformed and transformed data, respectively. All assumptions of linear regression were met when untransformed data were used; therefore, untransformed data were used throughout the data analysis.
For fish with ovaries at OSFD stage 2, the best model for the prediction of fecundity included carcass weight, LC oocyte diameter, and spawning year (Table 3, Suppl. Table 1) with fecundity being positively correlated with carcass weight and negatively correlated with LC oocyte diameter (Fig. 4). Fecundity was significantly lower in 2014 than in all other years, and in 2015 it was significantly higher than in all other years, as indicated by results from the Tukey's HSD test. Carcass weight was a better predictor of fecundity than length.

For fish with ovaries at OSFD stage 3 , carcass weight was a better predictor of fecundity than length. The best model for the prediction of fecundity included carcass weight, liver weight, date of capture, and LC oocyte diameter (Table 4, Suppl. Table 2). In this model, fecundity was positively correlated with carcass weight, liver weight, and date of capture and negatively correlated with LC oocyte diameter (Fig. 5). The addition of liver weight and LC oocyte diameter to the model, although both statistically significant, increased the explanatory power of the model by $<1.0 \%$ each (Suppl. Table 2). There was no significant difference in fecundity between years in the study period 2014-2019 (Fig. 6). Mean relative fecundity was 34,700 oocytes/kg body weight (standard deviation [SD] 5900).

Potential fecundity of fish with ovaries at OSFD stage 5 was, on average, 0.54 (SD 0.19) of the fecundity expected of fish with ovaries classified as in OSFD stage 3 on the basis of length (Fig. 7). These values were not significantly different from the expected value of 0.50 (Kennedy, 2018) (Student's $t$-test: $t=1.7, \mathrm{df}=63, P=0.09$ ). On removal of 4 outliers (Fig. 7), the average potential fecundity decreased to 0.50 (SD 0.12) of the fecundity expected of fish with ovaries classified as at OSFD stage 3 on the basis of length.

When data from 2009 were included in the general linear model of fecundity=carcass weight+liver weight+date

\section{Table 3}

Estimates of fecundity from the best general linear model for lumpfish (Cylopterus lumpus) with ovaries at oocyte size frequency distribution (OSFD) stage 2. This model included carcass weight, leading cohort (LC) oocyte diameter, and spawning year. Ovaries classified as at OSFD stage 2 contain a single group of oocytes between 400 and 1800 $\mu \mathrm{m}$ with a unimodal size frequency distribution. Fecundity estimates, obtained by using gravimetric and auto-diametric methods, are given in number of oocytes. The model was fit to data from fish sampled around Iceland during 2013-2019. SD=standard deviation.

\begin{tabular}{lrrrr}
\hline Term & Estimate & \multicolumn{1}{c}{ SD } & \multicolumn{1}{c}{$t$} & \multicolumn{1}{c}{$P$} \\
\hline (Intercept) & $51,5269.9$ & 38589.3 & 3.4 & $<0.0001$ \\
Carcass weight & 123.2 & 11.7 & 0.5 & $<0.0001$ \\
Spawning year: 2015 & $-17,0746.5$ & $25,611.0$ & 6.7 & $<0.0001$ \\
Spawning year: 2016 & $-84,873.4$ & $21,797.4$ & 3.9 & $<0.001$ \\
Spawning year: 2017 & $-81,345.8$ & $22,167.5$ & -3.7 & $<0.001$ \\
Spawning year: 2018 & $-51,092.5$ & $25,423.5$ & 2.0 & $<0.05$ \\
LC oocyte diameter & -244.8 & 15.0 & -16.3 & $<0.0001$ \\
& & & & \\
\end{tabular}




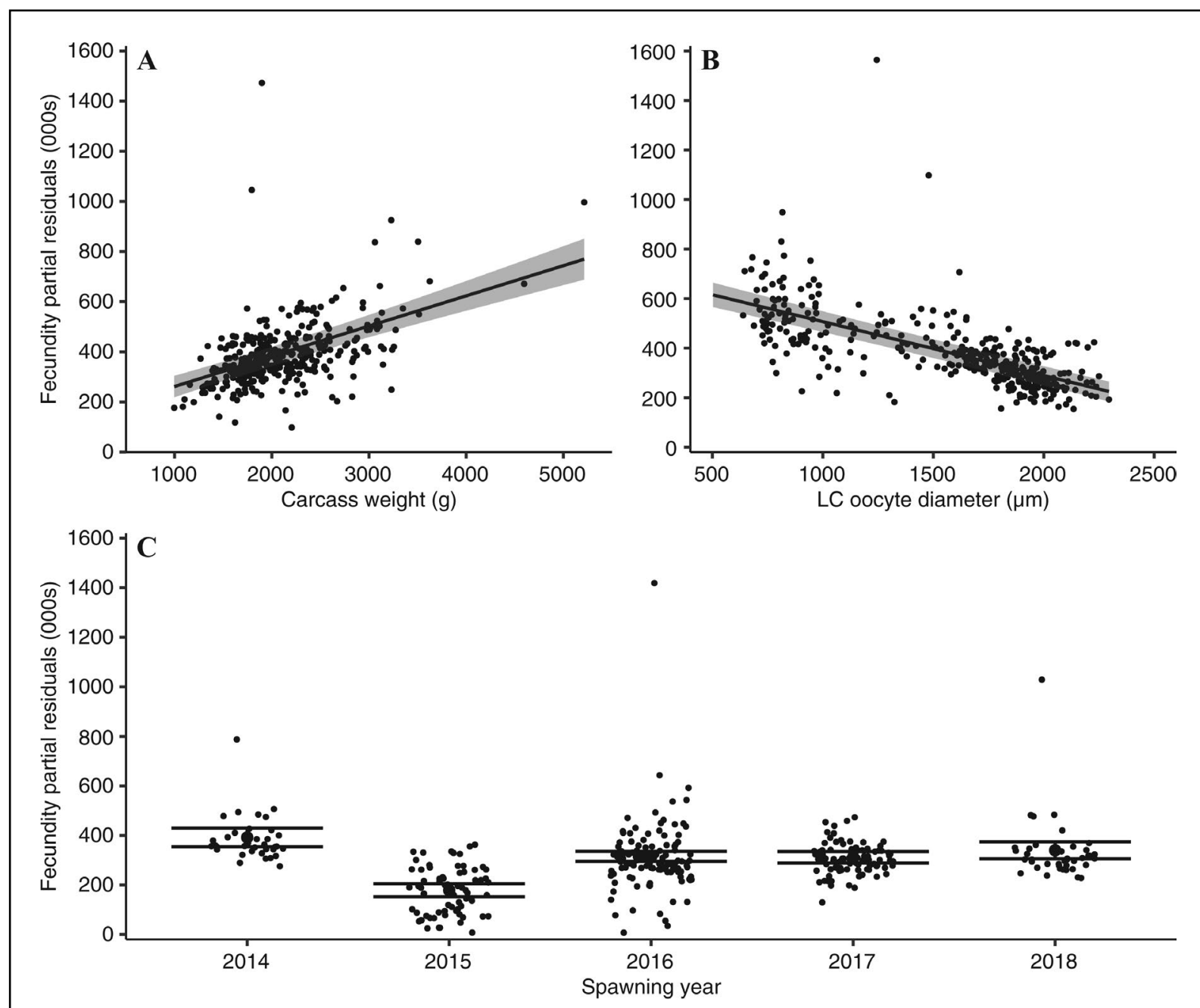

Figure 4

Plots of partial residuals for (A) carcass weight, (B) leading cohort (LC) oocyte diameter, and (C) spawning year, from the model that best explains the variability of fecundity in lumpfish (Cyclopterus lumpus) with ovaries at oocyte size frequency distribution (OSFD) stage 2. Ovaries classified as at OSFD stage 2 contain a single group of oocytes between 400 and $1800 \mu \mathrm{m}$ with a unimodal size frequency distribution. In panels A and B, the linear regression line is shown, and the gray shaded area indicates $95 \%$ confidence intervals. In panel $\mathrm{C}$, the horizontal lines indicate $95 \%$ confidence intervals. Fecundity estimates, obtained by using gravimetric and auto-diametric methods, are given in number of oocytes. The model was fit to data from fish sampled around Iceland during 2009 and 2013-2019.

of capture+year, spawning year was a significant factor in the model with fecundity significantly lower in 2009 than in $2015(P<0.01), 2016(P<0.05), 2017(P<0.01)$, and $2019(P<0.05)$ (Fig. 8). The result was similar when the data for back-calculated LC oocyte diameter was included in this general linear model. The biggest difference was between 2009 and 2017, with fecundity being 8.7\% lower in 2009 than in 2017 for a fish with an average carcass weight $(1860 \mathrm{~g})$, average liver weight (111 g), average date of capture (day 106), and average LC oocyte diameter $(2306 \mu \mathrm{m})$.

Fecundity estimates from 1967 and 1969 were significantly lower and significantly higher, respectively, than in all the years in our study when we used the model of fecundity=length + date of capture + year $(P<0.001)$ (Figs. 8 and 9). It should be noted that the use of length rather than carcass weight in the model gave a slightly different result in regard to differences in fecundity between 2009 and 2014-2019, with this difference no longer apparent when length was used as the covariate (Fig. 9).

\section{Egg size}

The general linear model revealed that $\log _{10}$-transformed average egg diameter was significantly correlated with $\log _{10}$-transformed carcass weight $(P<0.001)$. In addition, 


\section{Table 4}

Estimates of fecundity from the best general linear model for lumpfish (Cyclopterus lumpus) with ovaries at oocyte size frequency distribution (OSFD) stage 3. This model included carcass weight, liver weight, day of year captured, and leading cohort (LC) oocyte diameter. In ovaries classified as at OSFD stage 3, a break in size frequency distribution separates oocytes into a group of large oocytes (diameters $>1800 \mu \mathrm{m}$ ) that have a bimodal distribution and a group of small oocytes (diameters $\leq 1800 \mu \mathrm{m}$ ) that have a variable distribution. Fecundity estimates, obtained by using gravimetric and auto-diametric methods, are given in number of oocytes. The model was fit to data from fish sampled around Iceland during 2009 and 2014-2019. SD=standard deviations.

\begin{tabular}{lrrrr}
\hline Term & Estimate & \multicolumn{1}{c}{ SD } & $t$ & \multicolumn{1}{c}{$P$} \\
\hline (Intercept) & -3497.5 & $13,717.1$ & 0.3 & 0.80 \\
Carcass weight & 37.4 & 2.4 & 5.7 & $<0.0001$ \\
Liver weight & 76.6 & 30.8 & 2.5 & $<0.05$ \\
Day of year 2 & 301.7 & 28.8 & 0.5 & $<0.0001$ \\
LC oocyte diameter & -14.1 & 6.2 & 2.3 & $<0.05$ \\
& & & &
\end{tabular}

average egg diameter was significantly lower (approximately $1.6 \%$ ) for fish with ovaries at developmental stage spawning 2 than for fish with ovaries at the stage spawning $1(P<0.01)$. Average egg diameter was significantly different between years $(P<0.001)$ (Fig. 10); however, results of the Tukey's HSD test indicate that the only significant difference was between 2014 and 2016 $(P<0.05)$.

\section{Discussion}

Lumpfish add to a growing list of diverse fish species for which downregulation of fecundity, the process whereby the number of developing oocytes are reduced as ovary development progresses, has been documented (Vladykov, 1956; Kurita et al., 2003; Saborido-Rey et al., 2015; Flores et al., 2017). In many determinate spawners, there are several months between the commencement of ovary development, with the recruitment of previtellogenic oocytes to the developing pool of vitellogenic oocytes, and the spawning of these oocytes (Rijnsdorp, 1989; van Damme et al., 2009; Skjæraasen et al., 2017). Because the actual energy available for reproduction is difficult to forecast at this early stage of ovary development, more oocytes are recruited to the developing pool than could be taken to full development. As ovary development proceeds, the number of oocytes can be reduced, meaning they can be fine-tuned to the actual energy available through reabsorption of a portion of oocytes through atresia (Kraus et al., 2008; van Damme et al., 2009; Nissling et al., 2016). The energy that was invested into those oocytes can then presumably be made available for other purposes. This process, therefore, maximizes the number of eggs spawned given the amount of energy available.
This downregulation has an implication for the method used when investigating fecundity in fish. If a fish is sampled before downregulation is complete, then realized fecundity (number of eggs actually spawned) will be overestimated. Downregulation in lumpfish takes place mostly during OSFD stage 2. Fecundity decreases at OSFD stage 3 , and this decrease is relatively small. Therefore, fecundity of lumpfish can be reliably estimated when ovaries are in OSFD stage 3.

Carcass weight was the best predictor of fecundity and notably outperformed length. This result is consistent with findings from other studies of fish fecundity that indicate that body weight is generally a better predictor of fecundity than length (Koops et al., 2004; Rideout and Morgan, 2010; Tanaka et al., 2017). The addition of liver weight explained only a small percentage of the variation in fecundity. This finding corresponds with those of previous studies in which characteristics intended to measure "condition," or energy reserves, added little in comparison to the factors reflecting body size (Alonso-Fernández et al., 2009; Rideout and Morgan, 2010; Rogers et al., 2019). The reason that such indices of energy reserves have a minor effect on explained variance is likely that, when sampling fish close to spawning, the energy to be used for ovary development has already been transferred from storage to the gonads. Therefore, the remaining energy at the time of sampling consists mainly of the energy required to complete and survive spawning and would not be expected to correlate with fecundity.

It is interesting to note that fish spawning later in the year had a higher fecundity than fish spawning earlier. Intra-annual variation in batch fecundity of indeterminate spawners is well documented (Alheit, 1993), but such variation has rarely been documented in determinate spawners. One of the few examples was reported by 

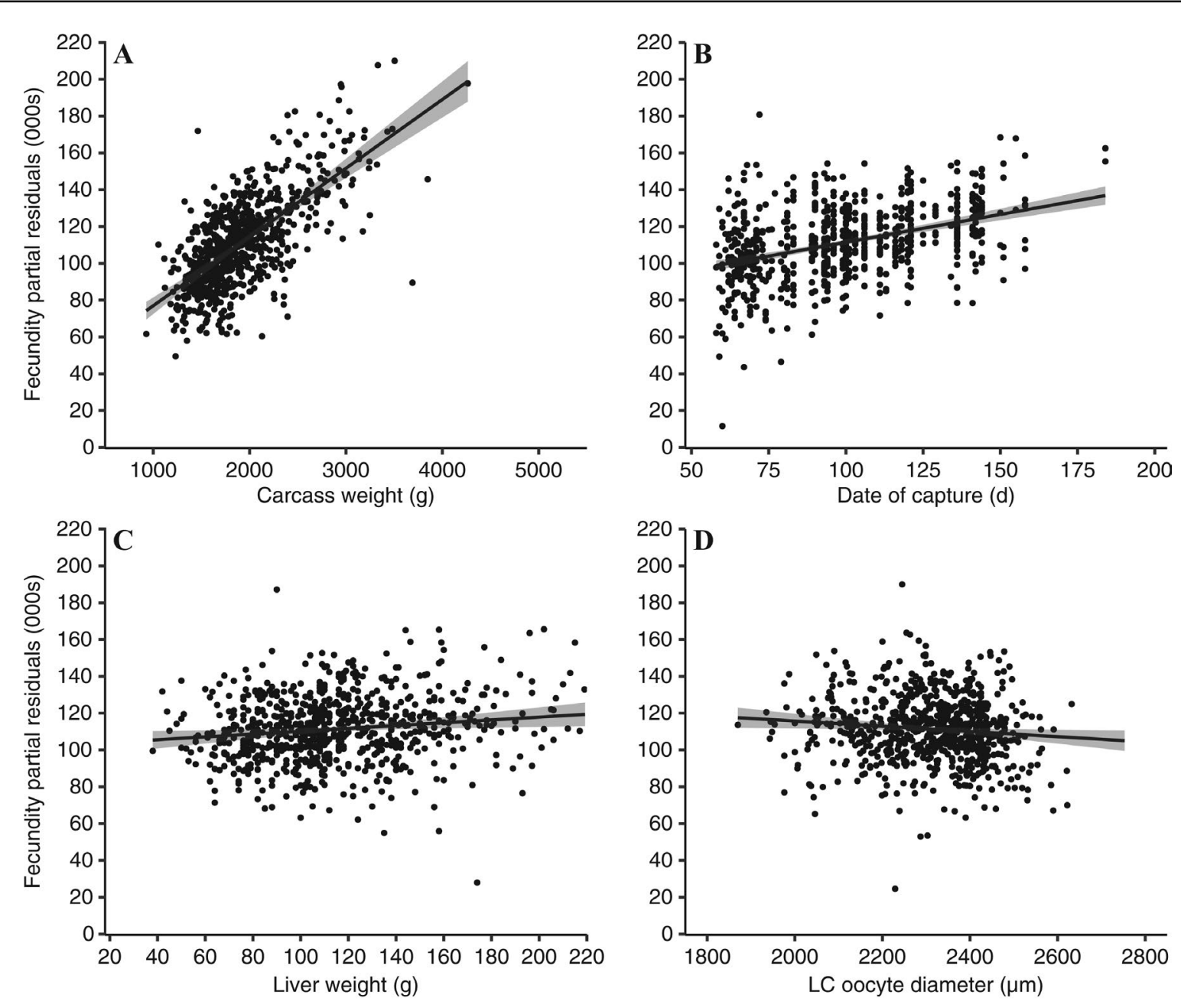

Figure 5

Plots of partial residuals for (A) carcass weight, (B) date of capture, (C) liver weight, and (D) leading cohort (LC) oocyte diameter, from the model that best explains variability in fecundity of lumpfish (Cyclopterus lumpus) with ovaries at oocyte size frequency distribution (OSFD) stage 3. In ovaries classified as at OSFD stage 3, a break in size frequency distribution separates oocytes into a group of large oocytes (diameters $>1800 \mu \mathrm{m}$ ) that have a bimodal distribution and a group of small oocytes (diameters $\leq 1800 \mu \mathrm{m}$ ). In each panel, the linear regression line is shown, and the gray shaded area indicates 95\% confidence intervals. For date of capture, 1 January was set as day 1 to aid interpretation. Fecundity estimates, obtained by using gravimetric and auto-diametric methods, are given in number of oocytes. The model was fit to data from fish sampled around Iceland during 2009 and 2013-2019.

Kjesbu et al. (1998), who found that fecundity was higher for Atlantic cod (Gadus morhua) that had already begun spawning than for fish that had not (i.e., early spawners had a higher fecundity than late spawners). The reason for this pattern in Atlantic cod was not clear, but Kjesbu et al. (1998) speculated that it was due to differences in sea temperatures between the timing of vitellogenesis of early and late spawners or was a result of the 2 groups belonging to different subpopulations. The results of our study and the fact that this aspect is rarely addressed in fecundity studies of determinate spawners highlight that a lack of variation in fecundity through the spawning season should not be assumed. Failure to investigate whether this variation indeed occurs in other species and populations could lead to bias when estimating the total egg production of a population or when using the annual egg production method for estimating spawning stock biomass.

What are the potential causes of this intra-annual variation in fecundity of lumpfish? Although the extent of the feeding area of lumpfish from Iceland is not fully known, there are indications that it may cover the Irminger Sea from southeastern Greenland, over the Denmark Strait and into the Norwegian Sea (Nøttestad 


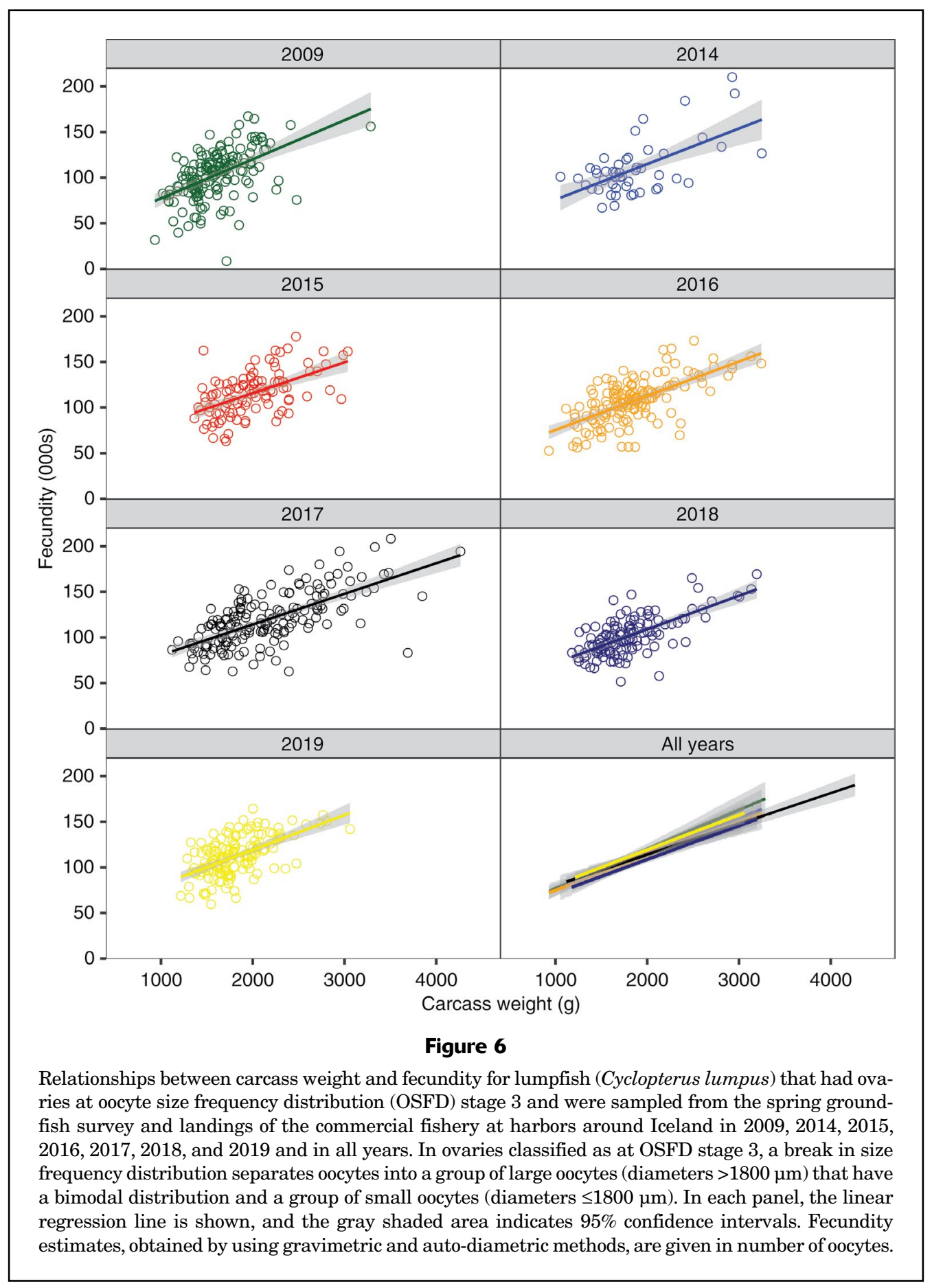

et al. ${ }^{2}$ ). Over this large area, there will be differences in biotic and abiotic conditions that could drive differences

\footnotetext{
${ }^{2}$ Nøttestad, L., V. Anthonypillai, S. Vatnehol, A. Salthaug, A. Høines, A. H. Ólafsdóttir, J. Kennedy, E. Homrum, L. Smith, T. Jansen, et al. 2019. Cruise report from the International Ecosystem Summer Survey in the Nordic Seas (IESSNS) 28th June-5th August 2019. Working document to ICES Working Group on Widely Distributed Stocks (WGWIDE, No. 5), Spanish Institute of Oceanography (IOE), Santa Cruz, Tenerife, Canary Islands, 28 August-3 September 2019, 48 p. [Available from website.]
}

in fecundity and spawning time in different parts of the population. In addition, if early and late spawners begin ovary development at different times of the year, the environmental conditions during vitellogenesis will differ, and that difference could also affect the resultant fecundity (Kjesbu et al., 2010). This aspect of fecundity of lumpfish is interesting in the context of the premise that lumpfish that spawn early or late in a spawning season will spawn early and late in the following season, respectively (Kennedy and Ólafsson, 2019). This intra-annual 


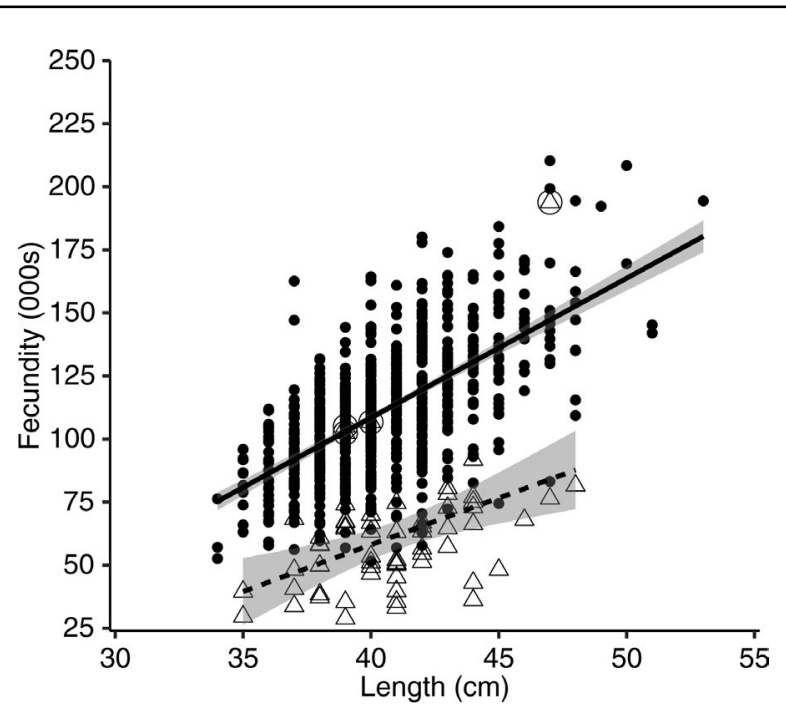

Figure 7

Relationship between total length and fecundity for all lumpfish (Cyclopterus lumpus) that had ovaries at oocyte size frequency distribution (OSFD) stages 3 (circles) and 5 (triangles) and were sampled from the spring groundfish survey and landings of the commercial fishery at harbors around Iceland during 2009 and 2014-2019. In ovaries classified as at OSFD stage 3 , a break in size frequency distribution separates oocytes into a group of large oocytes (diameters $>1800 \mu \mathrm{m}$ ) that have a bimodal distribution and a group of small oocytes (diameters $\leq 1800 \mu \mathrm{m}$ ). At OSFD stage 5, a break in size frequency distribution separates oocytes into a group of large oocytes (diameters $>1800 \mu \mathrm{m}$ ) that have a unimodal distribution and a group of small oocytes (diameters $\leq 1800$ $\mu \mathrm{m})$. Linear regression lines are shown for OSFD stages 3 (solid) and 5 (dashed), with 95\% confidence intervals represented by the gray shaded areas. Outliers are circled. Fecundity estimates, obtained by using gravimetric and auto-diametric methods, are given in number of oocytes.

difference in fecundity means that late-spawning fish, assuming similar spawning mortality, will have greater lifetime fecundity than early-spawning fish. However, greater lifetime fecundity may not translate into greater numbers of surviving offspring because mortality of lumpfish in early life stages may not be equal through the spawning season as a result of differing environmental conditions, prey availability, or predation (Methot, 1983; Narimatsu and Munehara, 1999; Voss et al., 2006).

Although there was interannual variability in the fecundity of lumpfish, the variability during 2009-2019 was low in comparison with the variability observed in other long-term studies of fish fecundity (Kjesbu et al., 1998; Kennedy et al., 2007; Rideout and Morgan, 2007). The extent to which fecundity varies between years in fish species is poorly understood because of a limited number of multiyear studies. Knowledge of what drives variability, or the lack thereof, is also limited, but there is some evidence that levels of specific prey items and abiotic conditions can play a role (Kjesbu et al., 1998). The reasons for the limited variability in fecundity between years observed in our study are unclear. It may be a result of stable environmental conditions and food availability in the years studied, or it may be that lumpfish place a high priority on reproduction and will maintain a similar level of fecundity from year to year at the expense of growth or energy reserves.

There were clear differences in fecundity in our study compared with historical estimates from Schopka (1970) and Myrseth (1971). Both studies used different methods in order to estimate fecundity. Schopka (1970) preserved the gonads in Gilson's fluid and used an automatic egg counter, and Myrseth (1971) froze ovaries and then used the gravimetric method. How the authors of the previous studies accounted for fish that had already spawned one batch differed. Schopka (1970) did not take it into account, and Myrseth (1971) included only fish in which the ovary filled the body cavity down to the abdomen in order to exclude any fish that had spawned one batch. Bear in mind that the number of fish that were caught in the commercial fishery and had ovaries at OSFD stage 5 in our study was low, approximately $7 \%$.

Inclusion of fish with ovaries assigned to OSFD stage 5 in fecundity estimates will lower the estimated population fecundity; however, exclusion of fish with small gonads has the potential to exclude fish with low fecundity and, therefore, lead to an overestimation of population fecundity. The fecundity estimates of 1969 are almost all within the upper range of expected values based on estimates from 2009 and 2014-2019. In contrast, the variability was lower in 1969 , and there is a notable lack of fecundity values within the lower range of values seen in 2009 and in 2014-2019. This lower variability and lack of fish within the lower range of fecundity values in 1969 indicates that the difference in fecundity between 1969 and the fecundity estimated in our study is largely driven by the bias in sampling in Myrseth (1971); therefore, the difference between the fecundity in 1969 and in 2009-2019 is likely a result of a difference in method.

In our study, no fish at OSFD stage 3, and approximately one third of fish at OSFD stage 5 , had a fecundity $<50,000$ oocytes. Only one fish from Schopka (1970) had a fecundity $<50,000$ oocytes, indicating that the occurrence of OSFD stage 5 was lower in the study of Schopka (1970) than in our study. This low occurrence of fish at OSFD stage 5 in Schopka (1970) indicates that not accounting for fish at this stage had no significant influence on the estimation of fecundity in 1967 and does not explain the low fecundity observed by Schopka (1970). However, because methods differed between studies (automatic egg counter, Parrish et al., 1960, versus autodiametric method), it is not possible to state with certainty that there is a real difference in fecundity between 


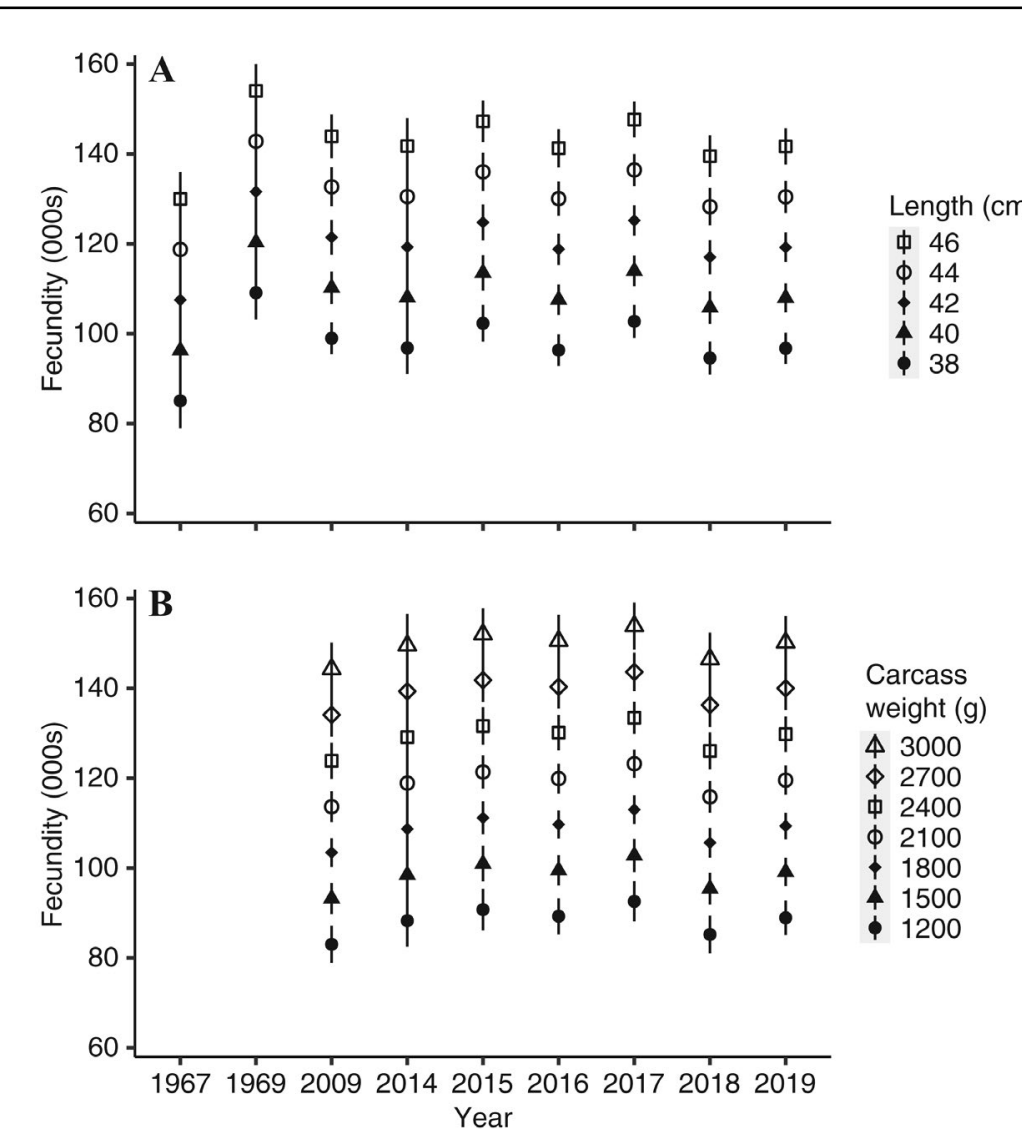

Figure 8

Values of fecundity predicted with a general linear model for lumpfish (Cyclopterus lumpus) at different (A) total lengths and (B) carcass weights. For each year, the average date of capture was set at 20 April in the model. For only analysis by carcass weight, the average liver weight used in the model was $111 \mathrm{~g}$. Data used in the model are from fish sampled for this study around Iceland during 2009 and 2014-2019; data for 1967 and 1969 are from previous studies (Schopka, 1970; Myrseth, 1971). study. Still, it is difficult to draw conclusions about whether fecundity of lumpfish in Greenland is lower, higher, or similar to that of lumpfish in Iceland. Hedeholm et al. (2017) did not consider temporal variations but did find spatial variation. In contrast, we did not investigate spatial variation but did find temporal variation. Therefore, differing conclusions could be drawn depending on how the comparison is carried out.

Fecundity has been estimated for lumpfish in Canada (Gauthier et al., 2017); unfortunately, the only information presented is fecundity versus ovary weight, making comparisons of the fecunditysize relationship difficult between fish from Iceland and those from Canada. The majority of the data from Gauthier et al. (2017) indicates that fecundity of lumpfish in Canada was 50,000-200,000 oocytes, similar to the range observed in our study; given the nature of the data presented, further comparisons between studies are not possible. Gauthier et al. (2017) also presented information on hydrated egg size, which probably refers simply to egg size because lumpfish do not hydrate their eggs. These egg size values ranged from $\sim 1.0$ to $\sim 2.0 \mathrm{~mm}$ with a median around $1.7 \mathrm{~mm}$. These sizes are considerably smaller than those of eggs sampled from fish captured in Iceland. Gauthier et al. (2017) measured eggs from histological sections, an approach that generally underestimates diameter in comparison with the methods employed during our study. Caution should be applied, therefore, when comparing the results of the 2 studies.

1967 and 2009-2019. It must also be noted that, even if the difference is real, the historical estimate covers only a single year and it is not possible to know if this was typical of the population around that time. Therefore, we cannot conclude, on the basis of data from this study, that there have been any significant changes in the reproductive capacity of the population of lumpfish over the past 50 years.

There are a small number of studies on fecundity of lumpfish in other areas; however, differences in fecundity between areas needs to be carefully considered. Fecundity in fish is highly variable both within and between years, and it can also vary spatially within a population (Morgan and Rideout, 2008). In a study of lumpfish in Greenland in 2012 and 2014 (Hedeholm et al., 2017), a lumpfish with a carcass weight of $2 \mathrm{~kg}$ had a fecundity of 100,000-120,000 oocytes, a value that is broadly similar to fecundity observed in our
The estimated relative fecundity from our study $(34,700$ oocytes/kg body weight) was slightly lower than the estimate from Pountney et al. (2020) $(40,400$ oocytes/kg body weight). The reasons for this difference may be that Pountney et al. (2020) counted all the oocytes $>370 \mu \mathrm{m}$, a threshold lower than that used in our study ( 1600-1800 $\mu \mathrm{m}$, depending on the oocyte distribution). Therefore, Pountney et al. (2020) likely included oocytes from the non-spawning group, meaning the group of oocytes between 400 and $1800 \mu \mathrm{m}$ in ovaries classified as at OSFD stage 3 that would have become atretic and not spawned (Kennedy, 2018). In addition, the fish examined by Pountney et al. (2020) were captive bred and would have experienced conditions different than those experienced by the wild fish collected in our study.

Fish with ovaries at OSFD stage 5 had a fecundity roughly half that of fish with ovaries at OSFD stage 3 


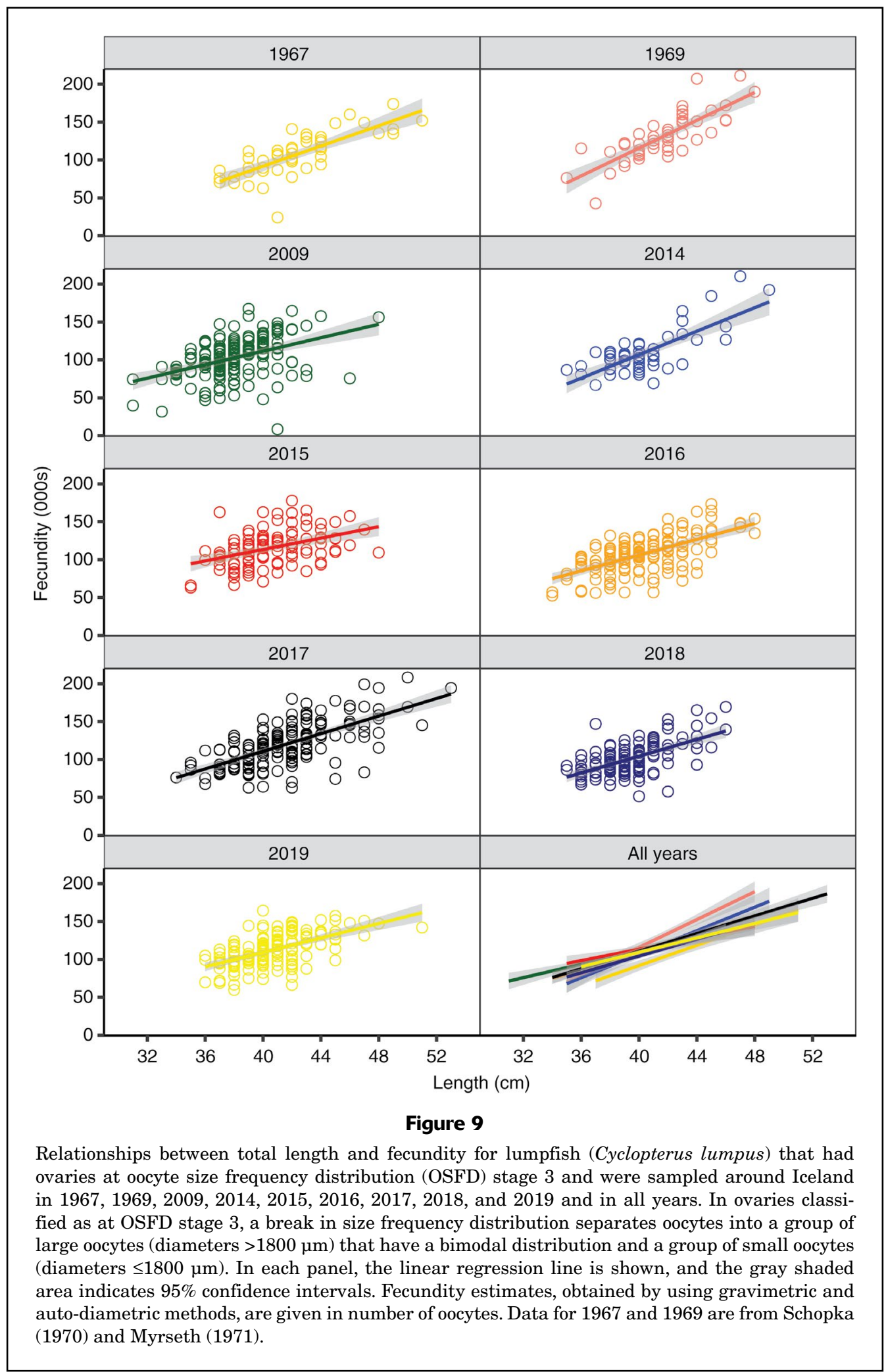



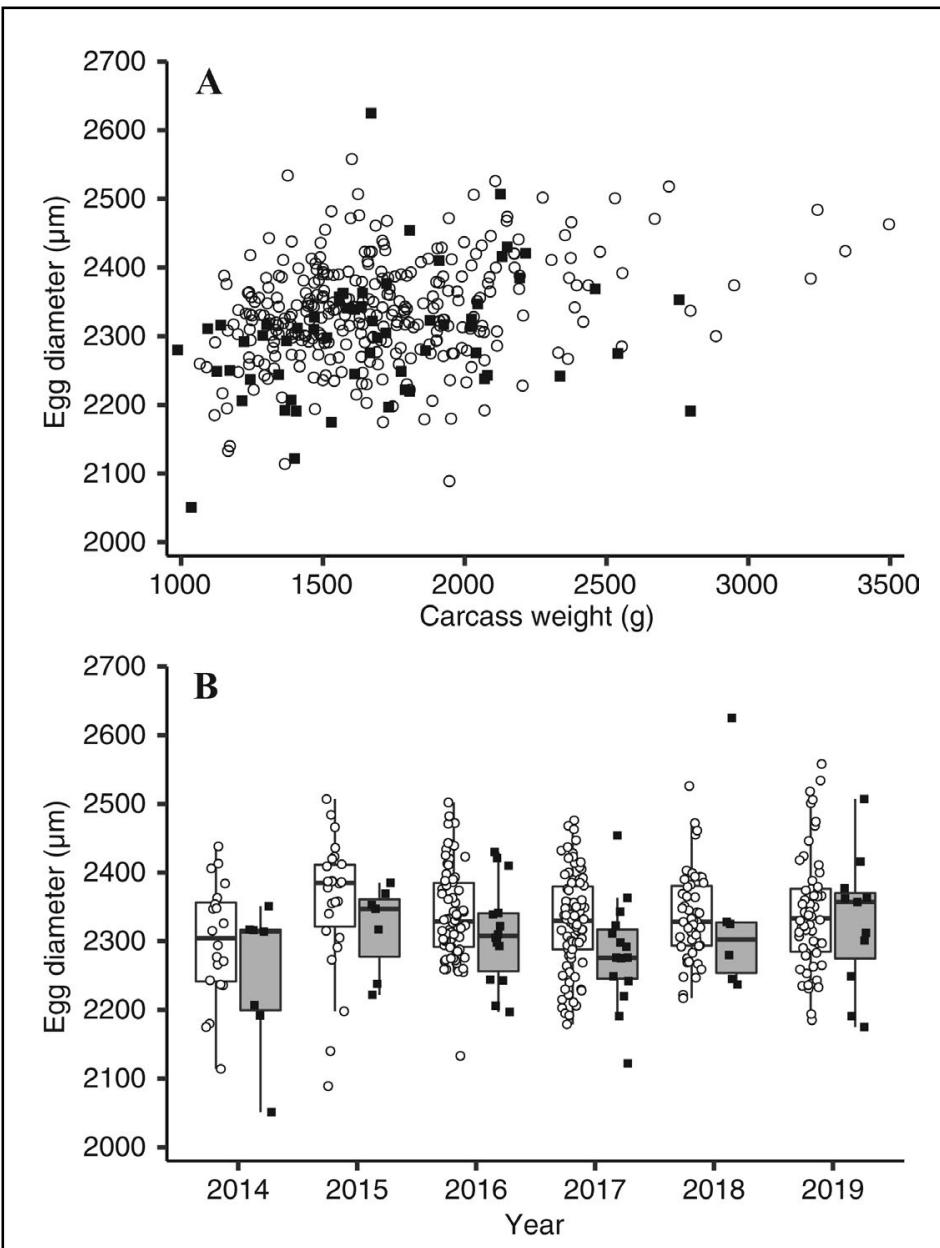

Figure 10

Average egg diameter as a function of $(\mathbf{A})$ carcass weight and $(\mathbf{B})$ year of capture for lumpfish (Cyclopterus lumpus) that were sampled around Iceland in 2014-2019 and had ovaries at the developmental stages spawning 1 (open circles) and spawning 2 (squares). At stage spawning 1, the first batch of eggs have been ovulated and the ovary also contains developing oocytes that will become the second batch. At stage spawning 2, the second batch of eggs have been ovulated. In panel B, the line within the box represents the median value. The bottom and top parts of the box represent the first and third quartiles (25th and 75th percentiles) of average egg diameter. Whiskers above and below the box correspond to 1.5 times the interquartile range. spawn only one batch of eggs. This phenomenon has been reported in lumpfish in an aquaculture scenario in which the incidence of singlebatch production was higher than in our study, with estimates of $50 \%$ for fish kept at $6^{\circ} \mathrm{C}$ and $9^{\circ} \mathrm{C}$ and of up to $78 \%$ for individuals held at $14^{\circ} \mathrm{C}$ (Pountney et al., 2020). The mechanisms behind this single-batch spawning remain unknown.

Egg size increased with carcass weight but decreased from the first batch to the second. This decrease from the first to second batch was investigated by Kennedy (2018), and with an additional 3 years of data from our study, this observation still holds. We also found low variation in egg size between years. Variability in egg size is a rarely investigated component of reproductive biology because of the number of confounding factors, such as fish size, progression through spawning for batch spawners, and the hydration of eggs for species with pelagic eggs. Although a few studies have investigated annual variation in egg size (Almatar and Bailey, 1989; DeMartini, 1990; Hinckley, 1990), a comprehensive investigation into annual variation across species is lacking. The information provided by this study should aid such a study in the future.

\section{Acknowledgments}

We would like to thank all the crew and scientific personnel who collected ovarian samples during the scientific surveys. We also are grateful to the fishermen who supplied us with fish. Appreciation goes to L. Kristjánsdóttir and H. Steinsdóttir, who assisted with the laboratory work, to A. Thorsen, who assisted with setting up the image analysis software, and to the 3 anonymous reviewers for their helpful comments on our manuscript. This work was funded by the Marine and Freshwater Research Institute and by Biopol ehf. irrespective of whether outliers were or were not excluded in the estimation of the average proportion of eggs spawned. This finding supports the conclusion of a previous study (Kennedy, 2018), based on oocyte size distributions, that lumpfish spawned 2 batches of eggs with a roughly equal number of eggs. However, in our study, there were 4 notable outliers with ovaries at OSFD stage 5 that had fecundity similar to fish with ovaries classified as at OSFD stage 3 . The existence of these outliers indicates that there may be a small number of individuals ( $0.5 \%$ in this study) that, without reduction in the total number of eggs spawned, will

\section{Literature cited}

Alheit, J.

1993. Use of the daily egg production method for estimating biomass of clupeoid fishes: a review and evaluation. Bull. Mar. Sci. 53:750-767.

Almatar, S. M., and R. S. Bailey.

1989. Variation in the fecundity and egg weight of herring $(\mathrm{Clu}$ pea Harengus L.). Part 1. Studies in the Firth of Clyde and northern North Sea. ICES J. Mar. Sci. 45:113-124. Crossref

Alonso-Fernández, A., A. C. Vallejo, F. Saborido-Rey, H. Murua, and E. A. Trippel.

2009. Fecundity estimation of Atlantic cod (Gadus morhua) and haddock (Melanogrammus aeglefinus) of Georges 
Bank: application of the autodiametric method. Fish. Res. 99:47-54. Crossref

Blanchard, J. L., K. T. Frank, and J. E. Simon.

2003. Effects of condition on fecundity and total egg production of eastern Scotian Shelf haddock (Melanogrammus aeglefinus). Can. J. Fish. Aquat. Sci. 60:321-332. Crossref

DeMartini, E. E.

1990. Annual variations in fecundity, egg size and condition of the plainfin midshipman (Porichthys notatus). Copeia 1990:850-855. Crossref

Ellis, J.

2015. Lumpfish (Cyclopteridae). In Fish atlas of the Celtic Sea, North Sea, and Baltic Sea (H. J. L. Heessen, N. Daan, and J. R. Ellis, eds.), p. 317-319. Wageningen Acad. Publ., Wageningen, Netherlands.

Eriksen, E., C. M. F. Durif, and D. Prozorkevich.

2014. Lumpfish (Cyclopterus lumpus) in the Barents Sea: development of biomass and abundance indices, and spatial distribution. ICES J. Mar. Sci. 71:2398-2402. Crossref

Flores, A., R. Wiff, E. Díaz, and B. Carvajal.

2017. Temporal variations of potential fecundity of southern blue whiting (Micromesistius australis australis) in the Southeast Pacific. J. Sea Res. 126:26-36. Crossref

Fulton, T. W.

1907. On the spawning of the lumpsucker (Cyclopterus lumpus) and the paternal guardianship of the eggs. Annu. Rep. Fish. Board Scotl. 24(part 3):169-178.

Gauthier, J., F. Grégoire, and C. Nozères.

2017. Assessment of lumpfish (Cyclopterus lumpus) in the Gulf of St. Lawrence (3Pn, 4RS) in 2015. Dep. Fish. Oceans, Can. Sci. Advis. Secr. Res. Doc. 2017/051, 47 p. [Available from website.]

Gregory, R. S., and G. R. Daborn.

1982. Notes on adult lumpfish Cyclopterus lumpus L. from the Bay of Fundy. Proc. N.S. Inst. Sci. 32:321-326.

Gundersen, A. C., K. H. Nedreaas, O. S. Kjesbu, and O. T. Albert. 2000. Fecundity and recruitment variability of Northeast Arctic Greenland halibut during 1980-1998, with emphasis on 1996-1998. J. Sea Res. 44:45-54. Crossref

Hedeholm, R. B., S. Post, and P. Grønkjær.

2017. Life history trait variation of Greenland lumpfish (Cyclopterus lumpus) along a $1600 \mathrm{~km}$ latitudinal gradient. Polar Biol. 40:2489-2498. Crossref

Hinckley, S.

1990. Variation of egg size of walleye pollock Theragra chalcogramma with a preliminary examination of the effect of egg size on larval size. Fish. Bull. 88:471-483.

Holst, J. C.

1993. Observations on the distribution of lumpsucker (Cyclopterus lumpus, L.) in the Norwegian Sea. Fish. Res. 17:369-372. Crossref

Kennedy, J.

2018. Oocyte size distribution reveals ovary development strategy, number and relative size of egg batches in lumpfish (Cyclopterus lumpus). Polar Biol. 41:1091-1103. Crossref

Kennedy, J., and S. P. Jónsson.

2017. Do biomass indices from Icelandic groundfish surveys reflect changes in the population of female lumpfish (Cyclopterus lumpus)? Fish. Res. 194:22-30. Crossref

Kennedy, J., and H. G. Ólafsson.

2019. Conservation of spawning time between years in lumpfish Cyclopterus lumpus and potential impacts from the temporal distribution of fishing effort. Fish. Manage. Ecol. 26:389-396. Crossref
Kennedy, J., P. R. Witthames, and R. D. M. Nash.

2007. The concept of fecundity regulation in plaice (Pleuronectes platessa) tested on three Irish Sea spawning populations. Can. J. Fish. Aquat. Sci. 64:587-601. Crossref

Kennedy, J., S. P. Jónsson, J. M. Kasper, and H. G. Ólafsson.

2015. Movements of female lumpfish (Cyclopterus lumpus) around Iceland. ICES J. Mar. Sci. 72:880-889. Crossref

Kjesbu, O. S.

1994. Time of start of spawning in Atlantic cod (Gadus morhua) females in relation to vitellogenic oocyte diameter, temperature, fish length and condition. J. Fish Biol. 45:719-735. Crossref

Kjesbu, O. S., P. R. Witthames, P. Solemdal, P., and M. G. Walker. 1998. Temporal variations in the fecundity of Arcto-Norwegian cod (Gadus morhua) in response to natural changes in food and temperature. J. Sea Res. 40:303-321. Crossref

Kjesbu, O. S., D. Righton, M. Krüger-Johnsen, A. Thorsen, K. Michalsen, M. Fonn, and P. R. Witthames.

2010. Thermal dynamics of ovarian maturation in Atlantic cod (Gadus morhua). Can. J. Fish. Aquat. Sci. 67:605-625. Crossref

Koops, M. A., J. A. Hutchings, and T. M. McIntyre.

2004. Testing hypotheses about fecundity, body size and maternal condition in fishes. Fish Fish. 5:120-130. Crossref

Kraus, G., J. Tomkiewicz, R. Diekmann, and F. W. Köster.

2008. Seasonal prevalence and intensity of follicular atresia in Baltic cod Gadus morhua callarias L. J. Fish Biol. 72:831-847. Crossref

Kurita, Y., S. Meier, and O. S. Kjesbu.

2003. Oocyte growth and fecundity regulation by atresia of Atlantic herring (Clupea harengus) in relation to body condition throughout the maturation cycle. J. Sea Res. 49:203219. Crossref

Marshall, C. T., O. S. Kjesbu, N. A. Yaragina, P. Solemdal, and Ø. Ulltang.

1998. Is spawner biomass a sensitive measure of the reproductive and recruitment potential of northeast Arctic cod? Can. J. Fish. Aquat. Sci. 55:1766-1783. Crossref

Mehault, S., R. Domínguez-Petit, S. Cerviño, and F. Saborido-Rey. 2010. Variability in total egg production and implications for management of the southern stock of European hake. Fish. Res. 104:111-122. Crossref

Methot, R. D.

1983. Seasonal variation in survival of larval northern anchovy, Engraulis mordax, estimated from the age distribution of juveniles. Fish. Bull. 81:741-750.

Morgan, M. J., and R. M. Rideout.

2008. The impact of intrapopulation variability in reproductive traits on population reproductive potential of Grand Bank American plaice (Hippoglossoides platessoides) and yellowtail flounder (Limanda ferruginea). J. Sea Res. 59:186-197. Crossref

Myrseth, B.

1971. Fekunditet, vekst, levevis og ernæring hos Cyclopterus lumpus L.: hovedoppgave i fiskeribiologi. M.S. thesis, 113 p. Univ. Bergen, Bergen, Norway. [In Norwegian.]

Narimatsu, Y., and H. Munehara.

1999. Spawn date dependent survival and growth in the early life stages of Hypoptychus dybowskii (Gasterosteiformes). Can. J. Fish. Aquat. Sci. 56:1849-1855. Crossref

Nissling, A., A. Thorsen, and F. F. G. da Silva.

2016. Fecundity regulation by atresia in turbot Scophthalmus maximus in the Baltic Sea. J. Fish Biol. 88:1301-1320. Crossref

Parrish, B. B., I. G. Baxter, and M. J. D. Mowat. 1960. An automatic fish egg counter. Nature 185:777. Crossref 
Pountney, S. M., I. Lein, H. Migaud, and A. Davie. 2020. High temperature is detrimental to captive lumpfish (Cyclopterus lumpus, L) reproductive performance. Aquaculture 522:735121. Crossref

$\mathrm{R}$ Core Team.

2019. R: a language and environment for statistical computing. R Foundation for Statistical Computing, Vienna, Austria. [Available from website, accessed August 2019.]

Rackovan, J. L., and W. H. Howell.

2017. Spatial and temporal distribution of juvenile Cyclopterus lumpus (lumpfish) in a New England estuary. Reg. Stud. Mar. Sci. 16:109-115. Crossref

Rasband, W. S.

2014. ImageJ. U.S. Natl. Inst. Health, Bethesda, MD [Available from website, accessed June 2014.]

Rideout, R. M., and M. J. Morgan.

2007. Major changes in fecundity and the effect on population egg production for three species of north-west Atlantic flatfishes. J. Fish Biol. 70:1759-1779. Crossref

2010. Relationships between maternal body size, condition and potential fecundity of four north-west Atlantic demersal fishes. J. Fish Biol. 76:1379-1395. Crossref

Rijnsdorp, A. D.

1989. Maturation of male and female North Sea plaice (Pleuronectes platessa L). ICES J. Mar. Sci. 46:35-51. Crossref

Rogers, R., S. Rowe, R. M. Rideout, and M. J. Morgan.

2019. Fecundity of haddock (Melanogrammus aeglefinus) off southern Newfoundland. Fish. Res. 220:105339. Crossref

Rosen, S., and J. C. Holst.

2013. DeepVision in-trawl imaging: sampling the water column in four dimensions. Fish. Res. 148:64-73. Crossref

Saborido-Rey, F., R. Domínguez-Petit, D. Garabana, and

P. Sigurðsson.

2015. Fecundity of Sebastes mentella and Sebastes norvegicus in the Irminger Sea and Icelandic waters. Cienc. Mar. 41:107-124. Crossref

Schopka, S. A.

1970. Vergleichende untersuchungen zur reproduktivität am hering (Clupea harengus L.), kabeljau (Gadus morhua L.) und seehasen (Cyclopterus lumpus L.) in NO-Atlantischen Gewässern. Ph.D. diss., 134 p. Christian-AlbrechtsUniversität Kiel, Kiel, Germany. [In German.]

Skjæraasen, J. E., J. A. Devine, J. A. Godiksen, M. Fonn, H. OtterÅ, O. S. Kjesbu, B. Norberg, Ø. Langangen, and Ø. Karlsen. 2017. Timecourse of oocyte development in saithe Pollachius virens. J. Fish Biol. 90:109-128. Crossref

Tanaka, H., T. Hamatsu, and K. Mori.

2017. Comparison of potential fecundity models for walleye pollock Gadus chalcogrammus in the Pacific waters off Hokkaido, Japan. J. Fish Biol. 90:236-248. Crossref

Thorsen, A., and O. S. Kjesbu.

2001. A rapid method for estimation of oocyte size and potential fecundity in Atlantic cod using a computer-aided particle analysis system. J. Sea Res. 46:295-308. Crossref

Todd, V. L. G., E. W. Lavallin, and P. I. Macreadie.

2018. Quantitative analysis of fish and invertebrate assemblage dynamics in association with a North Sea oil and gas installation complex. Mar. Environ. Res. 142:69-79. Crossref

Trippel, E. A.

1999. Estimation of stock reproductive potential: history and challenges for Canadian Atlantic gadoid stock assessments. J. Northwest Atl. Fish. Sci. 25:61-81. Crossref

van Damme, C. J. G., M. Dickey-Collas, A. D. Rijnsdorp, and O. S. Kjesbu.

2009. Fecundity, atresia, and spawning strategies of Atlantic herring (Clupea harengus). Can. J. Fish. Aquat. Sci. 66:2130-2141. Crossref

Vladykov, V. D.

1956. Fecundity of wild speckled trout (Salvelinus fontinalis) in Quebec lakes. J. Fish. Res. Board Can. 13:799-841. Crossref

Voss, R., C. Clemmesen, H. Baumann, and H. H. Hinrichsen.

2006. Baltic sprat larvae: coupling food availability, larval condition and survival. Mar. Ecol. Prog. Ser. 308:243-254. Crossref 